\title{
PROFIL DAN PERSEPSI NELAYAN TERHADAP PERUBAHAN HASIL TANGKAPAN IKAN PERAIRAN PANTAI DI TELUK AMBON
}

\author{
B.G. Hutubessy, F. Silooy, A. Tupamahu, S. Siaheinenia, J.B. Pailin, \\ R.H.S. Tawari \\ Jurusan Pemanfaatan Sumberdaya Perikanan, Fakultas Perikanan dan \\ IImu Kelautan, Universitas Pattimura, Ambon, Maluku, Indonesia \\ E-mail :grace.hutubessy@yahoo.com
}

Received February 2019, Accepted April 2019

\begin{abstract}
ABSTRAK
Nelayan mengetahui sumberdaya laut secara rinci, juga lingkungan mereka dan aktifitas penangkapan yang mereka lalukan, dan pengetahuan ini jarang dikoleksi secara sistimatik. Penelitian ini dilakukan untuk menguji persepsi nelayan terhadap perubahan hasil tangkapan dan penyebabnya. Kami mewawancarai nelayan Pantai Haive Besar dengan menggunakan kuisioner yang sifatnya semi terstruktur. Informasi pribadi nelayan seperti umur dan pengalaman menangkap ikan, aktifitas penangkapan seperti alat yang digunakan dan daerah penangkapan, serta pengetahuan mereka tentang perubahan ekosistem menjadi topik pertanyaan di dalam kuisioner. Nelayan dengan usia karir menengah (2135 tahun) lebih banyak dibandingkan nelayan usia karir muda dan karir tua. Nelayan mendeteksi perubahan pada ekosistem daerah penangkapan mereka seperti banyaknya sampah, limbah minyak, rusak dan berkurangnya habitat karang dan lamun serta kekeruhan. Dampak yang nelayan rasakan adalah hasil tangkapan yang semakin berkurang bahkan tidak ada lagi. Persepsi nelayan terhadap perubahan ekosistem dan hasil tangkapan mereka menjadi dasar bagi penelitian selanjutnya seperti fisheries assessment.
\end{abstract}

Kata Kunci : Profil Nelayan, Persepsi Nelayan, Perubahan Ekosistem, Hasil Tangkapan

\section{ABSTRACT}

FISHERS' PROFILE AND PERCEPTION ON THE SHIFTING OF CATCH ON THE COAST OF AMBON BAY. Fishers have detailed knowledge of their resources, their environment, and their fishing practices that is rarely systematically collected. This study was undertaken to examine perceptions of fishers on the shifting of catch and the occasion of the changing. We conducted an interview with coastal Hative Besar fishers using a semi-structured questioner. Fishers' profiles such as age and years at fishery, gears and fishing grounds was one part of the questions. 
Other part was fishers' ecological knowledge focused on environmental condition and shifting catch. More fishers with middle career (21-35 year in fishery) than young and old careers were interviewed. Environmental changes included waste in the water, oil, corals and seagrasses degradation, and turbidity affected the catch of fishers. Fish became difficult to be found. We learn from this study that fishers' perception is an important tool for further fisheries assessment study.

Keywords : Fishers' Profile, Fishers' Perception, Ecosystem Shift, Catch

\section{PENDAHULUAN}

Perairan Maluku sudah lama dilaporkan dalam kondisi yang sudah lebih tangkap (overfishing) (DKP, 2003). Dengan menurunnya CPUE, menandakan bahwa sumberdaya perikanan sudah berkurang sedangkan upaya penangkapan terus dilakukan. Bahkan, kondisi perikanan ini sudah dikategorikan dalam kondisi yang memprihatinkan, contohnya perairan Arafura (Heazel and Butcher, 2007). Salah satu penyebabnya adalah penambahan upaya penangkapan yang tidak didasari perhitungan yang teliti seperti tingginya hasil tangkapan melebihi ketersediaan sumberdaya di alam, sehingga upaya perikanan itu sediri tidak sedikit yang akhirnya mubasir.

Pengakuan tentang berkurangnya hasil tangkapan sudah cukup lama dialami oleh nelayan pantai hampir di semua perairan di Maluku. Perubahan ini dirasakan oleh nelayan yang secara langsung melakukan praktek penangkapan. Melalui wawancara secara personal kepada nelayan, dapat dikumpulkan banyak informasi baik tentang ikan ekonomis penting maupun yang kurang ekonomis sehubungan dengan aktifitas penangkapan (Hutchings, 1996), bahkan juga informasi tentang perubahan kelimpahan ikan berdasarkan laju penangkapan (Hutchings and Myers, 1994). Untuk wilayah yang kurang mempunyai data perikanan yang akurat (poor data), persepsi nelayan tentang perubahan sumberdaya laut atau dikenal dengan fishers' ecosystm knowledge dapat menjadi informasi yang berguna dalam pengelolaan perikanan di wilayah tersebut.

Daerah studi negeri Hative Besar merupakan desa pesisir berpenduduk nelayan skala kecil, salah satu desa pesisir dengan kondisi yang tidak berbeda dari desa pesisir lainnya yang memiliki perikanan tangkap skala kecil. Hasil penelitian sebelumnya yang tidak dipublikasikan (Hutubessy $d k k, 2018$ ) menunjukkan pancing adalah alat yang terbanyak dipakai. Pancing tonda, jaring hanyut, pukat cincin dan siru-siru (scoupnet) adalah alat tangkap lainnya yang dioperasikan nelayan Hative Besar dengan daerah penangkapan di sekitar Teluk Ambon. Dengan hanya berbekal perahu kecil tanpa motor penggerak, daerah penangkapan mereka tidak jauh dari rumah. Satu kebiasaan yang mereka sebut dengan tanuar adalah aktifitas penangkapan yang tergantung pada kemunculan ikan. Sebagai contoh, jika tanuar ikan tenggiri (Scombridae) maka nelayan akan menggunakan pancing dengan mata kail ukuran besar dan 
dioperasikan di waktu malam. Jika tanuar larva ikan sardine dan teri (Clupeidae), nelayan menggunakan siru-siru (scoupnet) untuk menangkap larva dengan bantuan lampu. Nelayan di negeri Hative Besar cenderung memiliki lebih dari satu alat tangkap dan dioperasikan sesuai dengan tanuar ikan. Kebiasaan ini diyakini telah memperkaya pengetahuan nelayan dan persepsi mereka terhadap perubahan yang terjadi merupakan masukan yang baik untuk menilai perikanan yang ada (Neis et al, 1999).

Menurunnya hasil tangkapan ikan yang menjadi target penangkapan sudah didokumentasikan dengan baik (Rosenberg et al, 2005), tetapi penyebab turunnya hasil tangkapan sering tidak terpantau oleh ilmuwan dan publik karena rendahnya sumberdaya sering dianggap normal (Pauly, 1995). Pada penelitian ini kami menggunakan persepsi nelayan untuk mendapatkan informasi tentang perubahan kondisi perikanan pantai di Teluk Ambon sebagai dasar penelitian penilaian perikanan (fisheries assessment) selanjutnya. Tujuan dari penelitian ini adalah untuk mempelajari profil nelayan pada salah satu desa nelayan di Teluk Ambon dalam hubungannya dengan persepsi mereka terhadap perubahan kondisi perikanan yang ada.

\section{MATERI DAN METODE}

\section{Waktu dan Tempat Penelitian}

Penelitian dilakukan di negeri Hative Besar, Kotamadya Ambon, pada bulan Juli - Agustus 2018. Yang menjadi responden adalah nelayan yang berdomisili di soa Wailete dan Waihoka. Dari 48 nelayan yang terdaftar di dua soa tersebut, 23 responden dipilih secara acak untuk diwawancarai.

Data dikumpulkan melalui wawancara kuisioner yang sifatnya semi terstruktur, yaitu pertanyaan yang diajukan bersifat kesinambungan tetapi tidak menutup kemungkinan munculnya pertanyaan yang di luar topik pembicaraan (Katikiro \& Mahenge, 2016). Informasi pribadi nelayan seperti umur dan pengalaman menangkap ikan, aktifitas penangkapan seperti alat yang digunakan dan daerah penangkapan, serta pengetahuan mereka tentang perubahan ekosistem menjadi topik pertanyaan di dalam kuisioner.

Tahun pengalaman sebagai nelayan dikelompokkan ke dalam usia karir yaitu karir muda, karir menengah dan karir tua. Karir muda merupakan kelompok umur dengan pengalaman $\leq 20$ tahun, karir menengah antara 20 dan 40 tahun, dan karir tua dengan umur pengalaman $\geq 40$ tahun (Neis et al., 1999). Analisa selanjutnya menggunakan kelompok karir untuk mengetahui persepsi nelayan terhadap perubahan ekosistem daerah penangkapan mereka. 


\section{Analisis Data}

Data umur (tahun) dan pengalaman perikanan (tahun) diuji normalitasnya dengan Kolmogorov-Smirnov test. Hasil test yang normal memungkinkan untuk menggunakan analisis regresi linier (SPSS 24) untuk mengetahui hubungan antara kedua data. Usia karir nelayan diuji dengan menggunakan One sample t-test.

\section{HASIL DAN PEMBAHASAN}

\section{Profil Nelayan}

Data umur dan pengalaman perikanan nelayan menyebar secara normal $(P=0.200)$ dan selanjutnya dapat diuji dengan analisa parametrik. Nelayan yang menjadi responden berumur antara 33 - 74 tahun dengan rata-rata $53.3 \pm 11.8 \mathrm{SD}$ tahun. Dari hasil wawancara, mereka mulai menangkap ikan sejak masih kecil, yaitu ketika menjadi siswa SMP. Pada penelitian ini, tidak ditemukan nelayan yang masih muda ( $<20$ tahun). Hal ini pertanda baik, di mana generasi muda belum terlibat dalam kegiatan perikanan karena mereka masih aktif dalam dunia pendidikan. Melalui pendidikan, generasi muda mendapatkan wawasan yang lebih baik untuk tidak menambah tekanan pada sumberdaya perikanan, sebaliknya berupaya untuk menjadi lebih baik dari generasi mereka sebelumnya. Sudah menjadi pengetahuan umum bahwa kehidupan nelayan sangat erat dengan kemiskinan dan rentan terhadap penyakit (FAO, 2007). Kemiskinan dalam kehidupan nelayan juga bisa berdampak pada lemahnya pengeloaan sumberdaya laut (FAO, 2007). Upaya kuat melalui pendidikan, kesehatan dan pendapatan terhadap komunitas nelayan tidak saja dapat mengentaskan kemiskinan tetapi juga membantu mereka meningkatkan kemampuan mengatasi permasalahan perikanan (FAO, 2007).

Pengalaman kerja sebagai nelayan rata-rata selama $31 \pm 14$ SD tahun. Pengalaman sebagai nelayan tercepat adalah 10 tahun dan terlama 54 tahun. Ketika dikelompokkan ke dalam usia karir, nelayan responden yang mewakili karir muda ( $\leq 20$ tahun) sebanyak $31 \%$, karir menengah $39 \%$ dan karir tua $30 \%$. Hasil $t$-test menunjukkan perbedaan dari masing-masing kelas usia ( $\mathrm{t}=11.5 ; \mathrm{P}=0.007)$. Hubungan antara umur nelayan dan pengalamannya dalam perikanan cenderung linier $(R=0.735)$ (Gambar 1). Semakin lanjut umur nelayan semakin berpengalaman mereka dalam beraktifitas menangkap ikan. Ketika digabungkan dengan kelompok usia dengan proporsi yang berbeda, terindikasi bahwa nelayan negeri Hative besar didominasi oleh usia produktif. Akan menjadi suatu kekuatiran jika proporsi nelayan dengan usia karir muda mendominasi suatu wilayah. Dengan kemampuan yang masih terbatas akan mengurangi daya jangkau mereka menuju daerah penangkapan yang jauh walaupun potensial. Akibatnya, dengan stamina tinggi yang dimiliki nelayan muda dapat menimbulkan tekanan penangkapan menjadi tinggi pada perairan yang dekat dengan homebase (Salas et al, 2004). 
Sebaliknya, jika komunitas nelayan didominasi kelompok karir tua, di mana mereka memiliki unit penangkapan yang lebih banyak (Neis et al, 1999), tetapi dengan stamina yang mulai menurun, keuntungan dari penangkapan juga tidak nampak. Dengan tingginya nelayan berkarir menengah di dalam komunitas, mengindikasikan adanya kesinambungan dalam mewariskan karir sebagai nelayan kepada generasi berikutnya.

Tabel 1. Hasil analisa One-sample t-test terhadap kelompok usia pengalaman perikanan

\section{One-Sample Test}

\begin{tabular}{|c|c|c|c|c|c|c|}
\hline \multicolumn{7}{|c|}{ Test Value $=0$} \\
\hline & \multirow[t]{2}{*}{$\mathrm{T}$} & \multirow[t]{2}{*}{ df } & \multirow[t]{2}{*}{$\begin{array}{l}\text { Sig. (2- } \\
\text { tailed) }\end{array}$} & \multirow[t]{2}{*}{$\begin{array}{c}\text { Mean } \\
\text { Difference }\end{array}$} & \multicolumn{2}{|c|}{$\begin{array}{l}95 \% \text { Confidence } \\
\text { Interval of the } \\
\text { Difference }\end{array}$} \\
\hline & & & & & Lower & Upper \\
\hline Kelusia & 11,500 & 2 & 007 & 7,667 & 4,80 & 10,54 \\
\hline
\end{tabular}

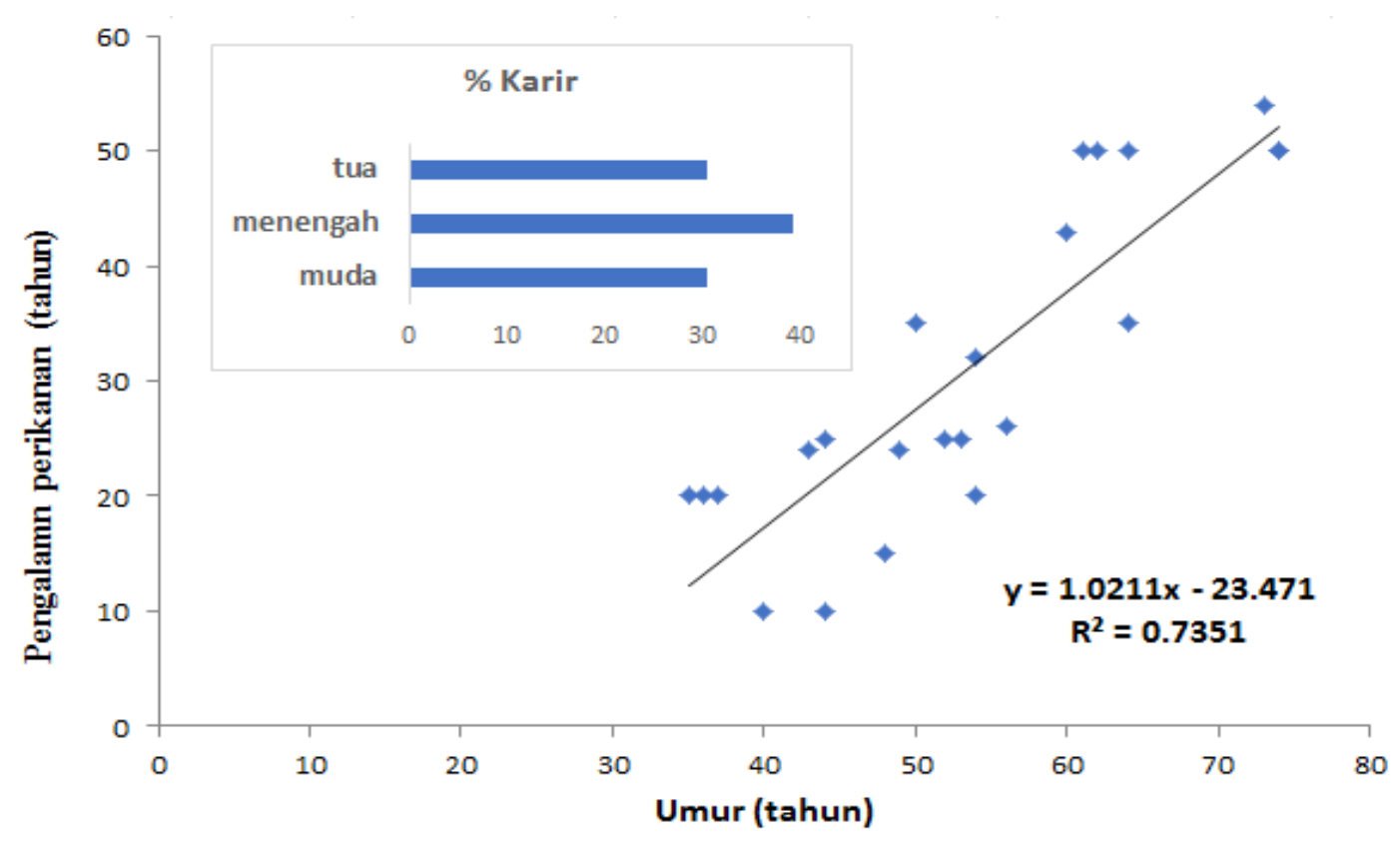

Gambar 1. Hubungan linier dan persamaan antara umur dan pengalaman perikanan serta proporsi usia karir nelayan (insert grafik)

Alat tangkap yang digunakan oleh responden nelayan Hative Besar terdiri dari 4 jenis: pancing (77.8\%), siru-siru $(11.1 \%)$, tonda $(7.4 \%)$ dan bubu (3.7\%). Hanya 4 nelayan (17.3\%) yang menggunakan lebih dari 1 (satu) alat tangkap, yang lainnya terfokus pada satu jenis alat tangkap yang didominasi oleh alat tangkap pancing. Siru-siru merupakan alat alternatif yang dipakai nelayan untuk menangkap larva ikan dengan bantuan lampu. Kehadiran larva ikan di teluk tidak terjadi setiap hari, tetapi tergantung pada musim pemijahan ikan pelagis kecil seperti ikan sardine 
(Sardinella spp) dan puri (Stolephorus spp) (Hutubessy 2009; Salhuteru, 2018).

Sesuai dengan alat yang digunakan dan target penangkapan, nelayan Hative Besar lebih banyak memilih habitat karang sebagai daerah penangkapannya, yaitu sebanyak $45.16 \%$. Selain karang, penangkapan juga dilakukan pada habitat batuan (16.13\%) (Tabel 2). Ini mengindikasikan bahwa ikan karang atau ikan demersal lainnya menjadi target penangkapan yang cukup besar. Hasil wawancara sebelumnya (Hutubessy $d k k, 2018$ ), nelayan cenderung melihat tanuar ikan, yaitu kemunculan suatu jenis ikan di dalam teluk. Sebagai contoh, jika muncul tanuar ikan layar, maka nelayan pancing akan menggunakan pancing yang ditonda untuk memangkap ikan tersebut. Jika tanuar ikan tenggiri, nelayan akan melakukan penangkapan di malam hari. Habitat daerah penangkapan bisa berubah-ubah sesuai dengan target ikan yang akan ditangkap. Perubahan habitat daerah penangkapan meyakinkan kami bahwa nelayan dapat mendeteksi perubahan lingkungan yang mempengaruhi hasil tangkapan.

Tabel 2. Jenis habitat daerah penangkapan nelayan Hative Besar disesuaikan dengan alat tangkap yang dipakai

\begin{tabular}{lcc}
\hline & Habitat & $\%$ \\
\hline Batuan & 5 & 16.13 \\
Karang & 14 & 48.38 \\
Pasir & 3 & 9.68 \\
Pelagis & 4 & 12.90 \\
Dalam Teluk & 2 & 6.45 \\
Tanjung Alang & 1 & 3.23 \\
Lainnya & 1 & 3.23 \\
\hline
\end{tabular}

\section{Persepsi Nelayan}

Perubahan ekosistem di sekitar daerah penangkapan nelayan Hative Besar menjadi perhatian nelayan. Ada 7 perubahan ekosistem perairan yang terdeteksi oleh nelayan yang dapat dilihat pada tabel 3 di bawah ini. Banyak sampah yang masuk ke dalam Teluk Ambon menjadi perhatian utama nelayan (43.38\%). Perubahan ini terjadi akibat perubahan jumlah penduduk yang semakin memadati Pulau Ambon sehingga sampah domestik tidak bisa lagi tertangani di darat sehingga laut turut menjadi tempat pembuangan akhir. Pada daerah penangkapan, sampah ikut terjaring bersama ikan (Hutubessy, 2016). Perubahan ekosistem lainnya yang cukup besar terdeteksi adalah perubahan warna air laut yang menjadi keruh (19.57\%) dan jumlah karang berkurang $(19.57 \%)$. Kepadatan penduduk yang meningkat mengakibatkan alih fungsi lahan di darat. Daerah hutan dan pegunungan sebagai daerah resapan air berubah menjadi daerah hunian sehingga air tawar dari darat 
tidak bisa terbendung menuju ke laut. Air laut yang keruh juga berakibat pada matinya karang karena berkurangnya cahaya matahari yang dibutuhkan bagi pertumbuhan karang melalui zoozanthella (Hughes et al., 2007).

Tabel 3. Perubahan ekosistem Teluk Ambon yang terdeteksi oleh nelayan di sekitar daerah penangkapan

\begin{tabular}{lcc}
\hline Jenis Perubahan ekosistem & Jumlah Nelayan & $\%$ \\
\hline Air laut tidak jernih & 9 & 19.57 \\
Banyak sampah & 20 & 43.48 \\
Karang berkurang & 9 & 19.57 \\
Karang hancur & 2 & 4.35 \\
Karang rusak & 1 & 2.17 \\
Ada minyak & 4 & 8.70 \\
Lamun berkurang & 1 & 2.17 \\
\hline
\end{tabular}

Dampak perubahan ekosistem sangat dirasakan oleh nelayan. Dampak tersebut antara lain: ikan susah didapat, laut tercemar, dan menangkap ikan menjadi lebih jauh. Nelayan melaporkan adanya minyak di permukaan air laut yang diduga merupakan pembuangan dari kapal dan galangan kapal yang ada di sekitar teluk. Selanjutnya, dampak pada hasil tangkapan ikan yang terdeteksi oleh nelayan hanya dua jenis, yaitu: hampir habis (15 nelayan) dan ikan tidak ada lagi (7 nelayan). Hal ini mengindikasikan perubahan ekosistem dan dampak yang semakin parah terjadi di Teluk Ambon.

Pernyataan nelayan mengenai ketersediaan sumberdaya ikan di Teluk Ambon berbeda menurut usia karir mereka (Gambar 2). Nelayan usia dengan karir muda dan karir tua menyatakan hasil tangkapan ikan hampir habis sebanyak $57 \%$ dan ikan sudah habis $43 \%$. Berbeda dengan nelayan berusia karir menengah, $87.5 \%$ merasakan ikan hampir habis dan $12.5 \%$ mengalami kesulitan memperoleh hasil tangkapan ikan. Hasil ini menggambarkan bahwa ikan sudah semakin sulit ditangkap pada perairan pantai di Teluk Ambon, dan nelayan dengan usia karir menengah lebih rasional menanggapi kondisi ini. Untuk kebutuhan penelitian fisheries assessment, nelayan dengan usia karir antara 21-35 tahun berpengalaman di bidang perikanan tangkap lebih direkomendasikan sebagai responden. 


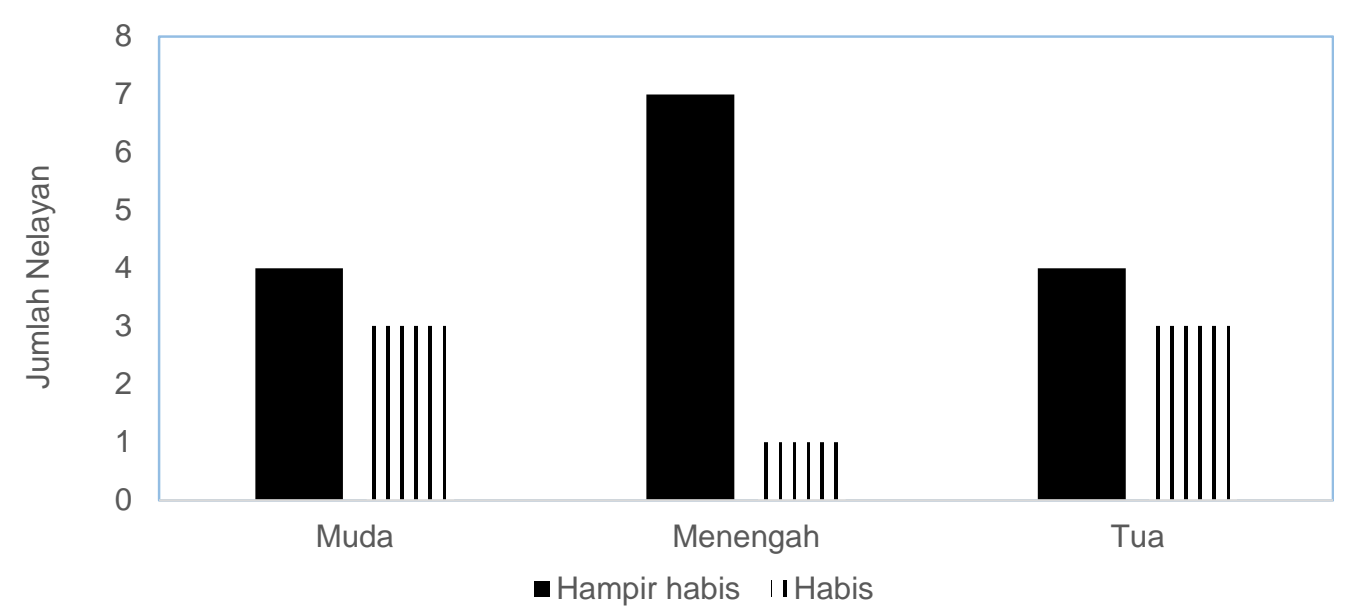

Gambar 2. Persepsi nelayan menurut usia karir terhadap sumberdaya ikan berdasarkan hasil tangkapan

\section{KESIMPULAN}

Teluk Ambon telah banyak megalami perubahan. persepsi nelayan menunjukkan sampah, kekeruhan, kerusakan karang, minyak dan berkurangnya karang berdampak pada berkurangnya hasil tangkapan, bahkan beberapa nelayan menyatakan ikan tidak ada lagi, sehingga nelayan harus menempuh jarak yang jauh untuk dapat menangkap ikan. Nelayan tidak lagi menyatakan ketersediaan ikan yang melimpah, melainkan semakin habis. Berdasarkan usia karir penangkapan ikan, hanya nelayan dengan usia karir menengah yang memberikan perspektif lebih baik terhadap hasil tangkapan mereka dibandingkan nelayan dengan usia karir muda dan karir tua.

\section{DAFTAR PUSTAKA}

Dinas Perikanan dan Kelautan Kota Ambon. 2003. Profil Sumber Daya Perikanan dan Kelautan Kota Ambon. Ambon (ID): Dinas Perikanan dan Kelautan Kota Ambon.

FAO. 2007. Poverty in fishing communities poses serious risks In addition to human costs, sound fisheries management suffers. www.fao.org/NEWSROOM/en/news/2007/1000544/index.html.

Heazel, M., and Bucher, J.G. 2007. Fisheries depletion and the state in Indonesia: Towards a a regional regulatory regime. Marine Policy 31: 276-286.

Hughes, T. P., Rodrigues, M. J., Bellwood, D. R., Ceccarelli, D., HoeghGuldberg, O., McCook, L., ... Willis, B. (2007). Phase Shifts, Herbivory, and the Resilience of Coral Reefs to Climate Change. Current Biology, 17(4), 360-365. https://doi.org/10.1016/j.cub.2006.12.049. 
Hutchings, J.A. 1996. Spatial and temporal variation in the density of northern cod and a review of hypotheses for the stock's collapse. Can. J. Fish. Aquat. Sci. 53: 943-962.

Hutchings, J.A., and Myers, R.A. 1994. What can be learned from the collapse of a renewable resource? Atlantic cod, Gadus morhua, of Newfoundland and Labrador. Can. J. Fish. Aquat. Sci. 51: 21262146.

Hutubessy, B.G. 2009. Pola kehadiran larva diTeluk Ambon. Prosiding seminar nasional kelautan Universitas Hangtuah, Surabaya.

Hutubessy, B.G., Nanlohy, A.Ch., Tuapetel, F., Silooy, Kesaulya, T., F., Tupamahu, A., Siahainenia, S.R., Paillin, J.B., Haruna, Tawari, R.H.S., Waeleruny, W., Matrutty, D.D.P. Matakupan, H., dan Noija, D. 2018. Persepsi neayan terhadap perubahan ekosistem dan perubahan hasil tangkapan. Makalah Pengabdian Masyarakat, Fakultas Perikanan dan IImu Perikanan Universitas Pattimura.

Hutubessy, B.G. 2016. Menjaring ikan menangkap sampah, mengapa tidak? Tribun Maluku.

Katikiro, R. E., \& Mahenge, J. J. (2016). Fishers' Perceptions of the Recurrence of Dynamite-Fishing Practices on the Coast of Tanzania. Frontiers in Marine Science, 3(November), 1-14. https://doi.org/10.3389/fmars.2016.00233.

Neis, B., Schneider, D. C., Felt, L., Haedrich, R. L., Fischer, J., \& Hutchings, J. A. (1999). Fisheries assessment: what can be learned from interviewing resource users? Canadian Journal of Fisheries and Aquatic Sciences, 56(10), 1949-1963. https://doi.org/10.1139/cjfas-56-10-1949.

Pauly, D., 1995. Anecdotes and the shifting baseline syndrome of fisheries. Trends in Ecology and Evolution 10, 430.

Rosenberg, A., Bolster, W.J., Alexander, K.E., Leavenworth, W.B., Cooper, A.B., McKenzie, M.G., 2005. The history of ocean resources: modeling cod biomass using historical records. Frontiers in Ecology and the Environment 3, 78-84.

Salas, S., Sumaila, U.R., and Tony, P. 2004. Short-term decisions of small-scale fishers selecting alternative target species: a choice model. Can.J.Aquat.Sci. 61: 374-383.

Salhuteru, C. 2018. Sebaran panjang larva ikan di Teluk Ambon. Skripsi mahasiswa S1 Universitas Pattimura, Ambon. 